\title{
https://doi.org/10.46813/2021-136-026 \\ RADIATION STIMULATION OF THE CATALYTIC ACTIVITY OF ZIRCONIUM DIOXIDE NANOPARTICLES DURING THE CONVERSION OF HYDROCARBONS
}

\author{
N.P. Dikiy, Yu.V. Lyashko, E.P. Medvedeva, D.V. Medvedev \\ National Science Center "Kharkov Institute of Physics and Technology", Kharkiv, Ukraine \\ E-mail: ndikiy@kipt.kharkov.ua
}

\begin{abstract}
The comparison of the catalytic activity of the initial and activated by bremsstrahlung $\gamma$-radiation on a highcurrent electron accelerator of zirconium dioxide nanoparticles on the nature of the conversion of ethanol. The used $\gamma$-activation parameters contributed to the formation of a more perfect crystal structure of $\mathrm{ZrO}_{2}$ nanoparticles. It was shown that when using $\gamma$-activated $\mathrm{ZrO}_{2}$ nanoparticles as a catalyst, the yield of hydrocarbon products during the conversion of ethanol was several times higher than the yield of the same products in the case of using the initial $\mathrm{ZrO}_{2}$ nanoparticles. The mechanism of such a conversion of ethanol can be associated with the synergism of large ionization losses of Auger electrons and the effect of highly reactive products involved in heterogeneous catalysis.

PACS: $81.16 . \mathrm{Hc}$
\end{abstract}

\section{INTRODUCTION}

The processing of organic raw materials into low molecular weight hydrocarbons is becoming one of the promising areas in the production of valuable chemical products. The implementation of this direction is associated with the creation of active, selective, and stable heterogeneous catalytic systems that do not contain expensive metals and harmful substances. The main reactions that take place during the conversion of hydrocarbons are dehydrogenation reactions, intermolecular dehydration, and intramolecular dehydration. The ethanol, ethers, ethylene, and acetaldehyde in the catalytic conversion been formed. Non-toxic zirconium dioxide can be used as a catalyst and carrier, and the use of zirconium dioxide nanoparticles is even more effective and promising [1 - 4].

Zirconium dioxide $\left(\mathrm{ZrO}_{2}\right)$ nanoparticles are a widely studied and demanded compound [5]. The main characteristics of $\mathrm{ZrO}_{2}$ are high hardness, refractoriness, low thermal conductivity and wear resistance, high refractive index and high radiation resistance [6].

The catalytic activity of $\mathrm{ZrO}_{2}$ provided due to its high acidity and due to the nature of the electronegative surface of this compound. The activity of a catalyst largely depends not only on the electronegative surface but also on the distribution of basic and acidic centers necessary for the directed development of the process. These uncoordinated metal cations and oxide anions can act as acids and bases. These are the so-called centers of Lewis acids - the proton theory of acids and bases, according to which acids (A) are able to donate protons, and bases (B) are capable of attaching them. " $\mathrm{A}$ " is the acceptor of this bond, and " $\mathrm{B}$ " is the donor of this bond (electronic theory of "A" and "B"). Coordination unsaturated cations that are present on the oxide surface can interact with the main molecules and create a new coordination bond while completing the complete coordination of the surface cations.

Accordingly, the high catalytic activity, for example, for $\mathrm{ZrO}_{2}$ in the conversion of hydrocarbons, can be associated with differences in acid-base characteristics, taking into account the highly electronegative cations of
"Lewis acids" such as $\mathrm{Zr}^{4+}, \mathrm{Ti}^{4+} \mathrm{Cr}^{3+}$. The high Lewis acidity of the surface increases the approach of the main reagents to the active sites and promotes strong interaction with metal cations. Apparently, the $\mathrm{ZrO}_{2}$ oxide catalyst will exhibit high conversion. On the other hand, the degree of polarization (the ratio of charge to ionic radius) can also affect the completeness of conversion. The stronger the polarization of the Lewis acid cation and the main strength of the adsorbent will be increased the power of the surface Lewis centers. Thus, compounds with $\mathrm{Zr}^{4+}, \mathrm{Ti}^{4+} \mathrm{Cr}^{3+}$, for which the degree of polarization is $6.2,6.6$, and 4.9 , respectively, should increase the interaction of Lewis centers with hydrocarbon molecules. The use of mixed oxide catalysis of the $\mathrm{ZrO}_{2} / \mathrm{Fe}_{2} \mathrm{O}_{3}$ type in comparison with mono catalysts can significantly increase the reaction yield due to the additional acidity of Lewis acids, as result of the presence of $\mathrm{Fe}^{3+}$ ions on the oxide surface.

Recently, in the field of heterogeneous catalysis, much attention has be paid to the effects of mutual amplification of various factors, for example, the treatment of catalysts with ultrasound, microwave radiation, the use of accelerator technology, and nuclear technologies. Until now, no studies devoted to influence of gamma activation of metal oxide nanoparticles by bremsstrahlung $\gamma$-radiation from an electron accelerator. Preliminary studies carried out by us [7 - 10] showed that Auger electrons appear in metal oxide nanoparticles after $\gamma$-activation. The various radiation defects (interstitial atoms and vacancies, highly reactive oxygen forms, etc.) which can lead to an increase in the concentration of active centers on the surface of the oxide and, as a consequence, to an increase in its catalytic activity [11 13]. The effectiveness of a catalyst determine by its ability to create active oxygen centers for breaking the $\mathrm{CH}$ bond in hydrocarbon molecules. The activity of catalysts also largely depends on the size of the nanoparticles used as catalysis.

The basic principles of the catalysts, their activity, and their selection for the oxidation reaction of hydrocarbons are still unresolved.

The aim of this work was to study the effect of gamma activation on the properties of nanoparticles of 
zirconium dioxide and on their catalytic activity during the conversion of ethanol.

\section{MATERIALS AND METHODS}

In the experiments, we used zirconium dioxide nanoparticles $(40 \mathrm{~nm})$ manufactured by Alta Aesar Sigma. Zirconium dioxide $\mathrm{ZrO}_{2}$ nanoparticles were activated by gamma bremsstrahlung from the NSC KIPT linear accelerator with $\mathrm{E}=22 \mathrm{MeV}, \mathrm{I}=500 \mu \mathrm{A}$ according to the reaction ${ }^{90} \mathrm{Zr}(\gamma, \mathrm{n})^{89} \mathrm{Zr},{ }^{96} \mathrm{Zr}(\gamma, \mathrm{n}){ }^{95} \mathrm{Zr}$. The maximum absorbed dose was $22 \mathrm{MGy}$. The gamma-ray spectrum was recorded with a $\mathrm{Ge}(\mathrm{Li})$-detector.

Auger electrons with energies of $1.91(78.6 \%)$ and $12.7(19.2 \%) \mathrm{keV}$ accompany the decay of ${ }^{89} \mathrm{Zr}$.

Registration of IR spectra of zirconium dioxide nanoparticles been carried out on a Specord-75 IR in the frequency range $4000 \ldots 400 \mathrm{~cm}^{-1}$ on samples in the form of tablets prepared by pressing with $\mathrm{KBr}$ [14].

The catalytic activity of the initial and gammaactivated nanoparticles of zirconium dioxide been compared by the optical density of hydrocarbon products that were formed in the process of ethanol conversion, as well as by the dynamics of the formation of highly reactive products by recording it is on a quantum installation with photomultiplier-39 [15].

\section{RESULTS AND DISCUSSION}

In Fig. 1 shows the gamma spectrum of zirconium dioxide nanoparticles.

In the gamma spectrum of zirconium dioxide from the reactions ${ }^{90} \mathrm{Zr}(\gamma, \mathrm{n}){ }^{89} \mathrm{Zr}$ and ${ }^{96} \mathrm{Zr}(\gamma, \mathrm{n}){ }^{95} \mathrm{Zr}$ the presence of impurity elements been not recorded. The presence of isotopes ${ }^{95} \mathrm{Zr}(511 \mathrm{keV}),{ }^{95} \mathrm{Zr}(757 \mathrm{keV}),{ }^{89} \mathrm{Zr}(909$, $1654,1712,1744 \mathrm{keV})$ is noted.

In Fig. 2 shows the IR spectra of initial and $\gamma$-activated $\mathrm{ZrO}_{2}$ nanoparticles.

The spectra exhibit absorption bands with a maximum at 745 and a doublet at 490 and $430 \mathrm{~cm}^{-1}$, which refer to asymmetric $\mathrm{Zr}-\mathrm{O}_{2}-\mathrm{Zr}$ and stretching $\mathrm{Zr}-\mathrm{O}$ vibrations, respectively.

It shown by IR spectroscopy that there are no significant differences in the IR spectra of the initial and activated nanoparticles of zirconium dioxide. The nature of the location of the maxima in the absorption region, their width, and intensity indicate high crystallinity. There is a fundamental spectral similarity of the samples before and after activation: the spectral profiles are practically identical in shape. This indicates that in the activated nanoparticles of zirconium dioxide, the mono phase, and crystal structure characteristic of the initial sample been retained. Such oxide samples with a cubic structure been characterized by pronounced stability. The retention of the absorption bands of the lattice vibrations of $\mathrm{ZrO}_{2}$ and the constancy of their intensities indicate the identity of the research conditions.

Neither shifts of the maxima nor have distortions of their shape not been found when comparing these samples. Minor differences were associated with changes in the intensity and integral area of the main peaks. In the samples after gamma activated, the intensity of some lines increased and their broadening been observed. This indicated that the parameters of gamma activation of $\mathrm{ZrO}_{2}$ nanoparticles contributed to the formation of a more perfect crystal structure of $\mathrm{ZrO}_{2}$, which facilitated its dispersion.

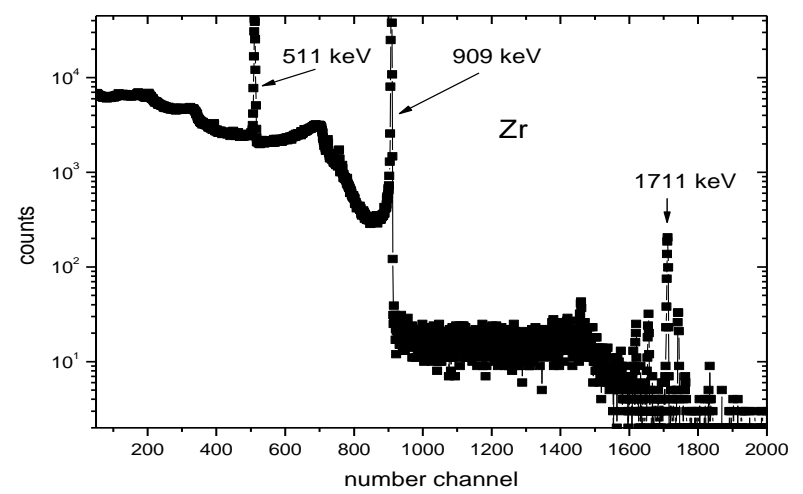

Fig. 1. The gamma spectrum of $\mathrm{ZrO}_{2}$ nanoparticles

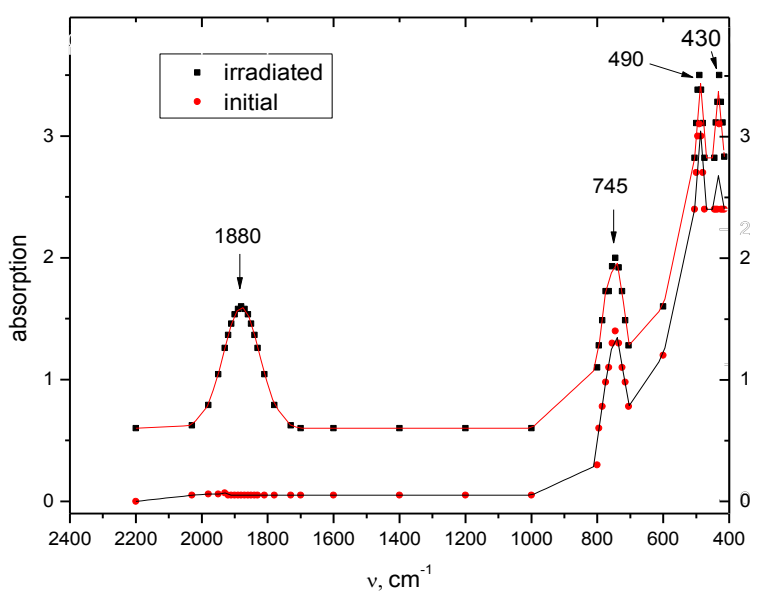

Fig. 2. IR spectra of pure nano- $\mathrm{ZrO}_{2}$ (initial) and after exposure to $\gamma$-radiation on the nano- $\mathrm{ZrO}_{2}$

Diffraction patterns of zirconium dioxide nanoparticles in the initial state and after irradiation to an absorbed dose of 22 MGy represent a polycrystalline monophasic sample containing a monoclinic and cubic modification.

Under the microscope, $\mathrm{ZrO}_{2}$ crystals are dense crystals with a glassy sheen and iridescent rings on the surface. Individual crystals had the shape of polyhedrons, which were separated by an accumulation of pores [7 - 13].

The structure of zirconium dioxide has a significant effect on its activity in various catalytic processes; therefore, ethanol conversions on the initial and activated $\mathrm{ZrO}_{2}$ samples been studied.

The catalytic activity of $\mathrm{ZrO}_{2}$ in the conversion of ethanol been estimated from the values of the optical density of the released products on spectrophotometer SF-46, as well as the intensity of free radical products on a quantum installation with a photoelectric multiplier (PEM-39). Measurements been carried out in dynamics after 1, 3 and 5 hours.

All results showed a significant increase in the catalytic activity of $\mathrm{ZrO}_{2}$ nanoparticles after their $\gamma$-activation. When using $\gamma$-activated $\mathrm{ZrO}_{2}$ nanoparticles, products such as dimethyl ether $(\lambda=245 \mathrm{~nm})$, diene ions $(\lambda=335 \mathrm{~nm})$, aromatic products $(\lambda=395 \mathrm{~nm})$ were also determined.

The optical density of the absorption spectra of the reaction products of the catalytic oxidation of ethanol 
with the participation of the initial and activated $\mathrm{ZrO}_{2}$ nanoparticles had the following values:

- after 1 hour for the initial $\mathrm{ZrO}_{2}$ nanoparticles are 0.073 rel. units and for activated $\mathrm{ZrO}_{2}$ nanoparticles 0.241 rel. units;

- after 3 hours -0.048 rel. units and 0.225 rel. units, respectively;

- after 5 hours - 0.0021 rel. units and 0.347 rel. units.

From the data presented, one can see the advantage in catalytic processes of $\gamma$-activated $\mathrm{ZrO}_{2}$ nanoparticles in comparison with the initial samples. The observed effect can be explained, firstly, by the large ionization losses of Auger electrons from the ${ }^{89} \mathrm{Zr}$ isotope and, secondly, by the gamma-induced chemisorption of oxygen $\mathrm{O}_{2}^{-}$on the catalyst surface due to the lattice oxygen released as a result of $\mathrm{ZrO}_{2}$ radiolysis. An increase in the catalytic activity of $\gamma$-activated zirconium dioxide nanoparticles, apparently, can be associated with an increase in the activity of the oxide surface because of the action of bremsstrahlung $\gamma$-radiation and Auger electrons from ${ }^{95} \mathrm{Zr}$ and ${ }^{89} \mathrm{Zr}$ (see Fig. 3).

In Fig. 3 shows the dynamics of the accumulation of free radicals during ethanol oxidation using the initial and $\gamma$-activated $\mathrm{ZrO}_{2}$ nanoparticles.

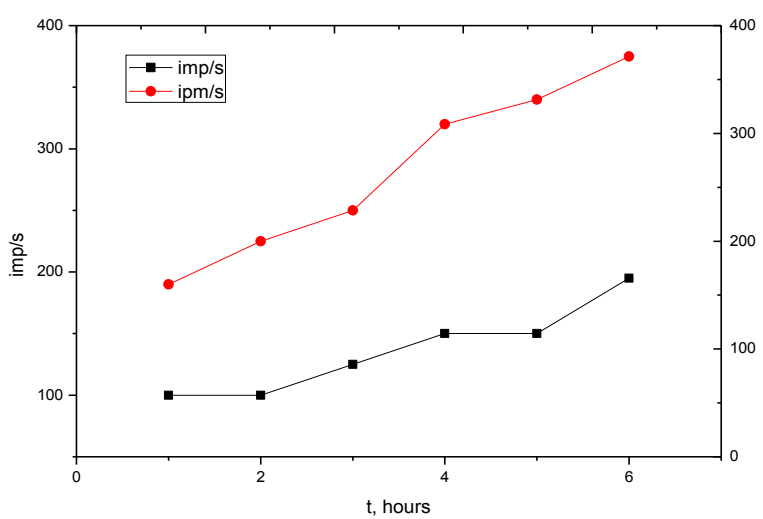

Fig. 3. The dynamics of the accumulation of free radicals during the oxidation of ethanol using the initial (a) and activated nanoparticles (•), error $20 \%$

The process of $\gamma$-activation of samples of zirconium dioxide nanoparticles can lead to the appearance on the surface of nanoparticles of possible radiation defects, such as vacancies of oxygen ions, interstitial metal ions, and conduction electrons. In addition, this, in turn, effectively affects the adsorption properties of a given sample. Atmospheric oxygen molecules can capture part of the electrons in surface anion vacancies, since the irradiation had carried out in the air, resulting in the formation of adsorbed oxygen $\mathrm{O}_{2}^{-}$ads. The adsorbed oxygen $\mathrm{O}_{2}^{-}$ads play an essential role in the initiation of the oxidation of hydrocarbons [16].

The initial samples of zirconium dioxide nanoparticles showed significantly lower activity in the values of the absorption spectra of the products of the catalytic oxidation of ethanol.

The intensity of free radical formation had more pronounced when using $\gamma$-activated $\mathrm{ZrO}_{2}$ nanoparticles. The direct effect of Auger electrons on zirconium diox- ide nanoparticles creates a reaction medium in which the formation of highly reactive oxygen forms such as hydroxyl radicals $\left(\mathrm{OH}^{*}\right)$, peroxides $\left(\mathrm{H}_{2} \mathrm{O}_{2}\right)$, which actively participate in the accelerated conversion reaction, is possible. Therefore, the registration time of the formation of free radical products during the conversion of ethanol in the presence of activated nanoparticles of $\mathrm{ZrO}_{2}$ catalyst been accelerated by almost an order of magnitude.

$$
\begin{gathered}
\mathrm{ZrO}_{2}+h v \rightarrow \mathrm{ZrO}_{2}+e^{-}+h, \\
\mathrm{e}^{-}+\mathrm{O}_{2}^{-} \rightarrow{ }^{-} \mathrm{O}_{2}^{-} .
\end{gathered}
$$

\section{CONCLUSIONS}

1. The possibility of using high-power electron beams at a high-current accelerator for the activation of zirconium dioxide nanoparticles been shown.

2. Comparative analysis of the phase composition and state of the crystal structure of the initial and gamma-activated nanoparticles of zirconium dioxide showed that the parameters activations contributed to the formation of a more perfect crystal structure of $\mathrm{ZrO}_{2}$.

3. The catalytic ability of $\mathrm{ZrO}_{2}$ nanoparticles after $\gamma$-activation is several times higher than initial of $\mathrm{ZrO}_{2}$ nanoparticles. The conversion of ethanol been accelerated due to the synergism of radiation-induced Auger electrons and active centers on the $\mathrm{ZrO}_{2}$ surface.

\section{REFERENCES}

1. A.A. Refaat. Biodiesel production using solid metal oxide catalysts // Int. J. Environ. Sci. Tech. 2011, v. 8, p. 203-221.

2. P.D.L. Mercera, V.J.G. Ommen, E.B.M. Doesburgh. Zirconia as a support for catalysis - evolution of the texture and structure on calcination in air // Appl. Catalysis. 1990, v. 57, p. 127-148.

3. R.A. Andrievski. Behavior of radiation defects in nanomaterials // Rev. Adv. Mater. Sci. 2011, v. 29, p. 54-67.

4. R.A. Andrievski, A.A. Klyuchareva. Radiation processes in nanomaterials // J. Nanopart. Research. 2011, v. 110, p. 6221-6230.

5. T.K.S.P. Gupta, S.S. Verma. Nanomagnetic Materials // Nanotech. 2003, v. 3, p. 281-292.

6. Y. Murase, E. Kato. Role water varop in crystalline growth and tetragonal-monoclie phase transformation of $\mathrm{ZrO}_{2} / /$ J. Am. Ceram. Soc. 1983, v. 66, p. 196-200.

7. N.P. Dikiy, A.N. Dovbnya, E.P. Medvedeva, et al. Gamma-activation and spectral analysis of element composition, structure and sorption activity radiation synthesized magnetic nanoparticles thermoupdating nanopowder natural clinoptilolite // Vesnyk KNU. Series "Phys. Nucl., Part., Fields”. 2008, № 823, iss. 3(39), p. 781-784.

8. N.P. Dikiy, E.P. Medvedeva, I.D. Fedorets, et al. Structure and magnetic properties of gamma activated nanoparticales of magnetite // Vesnyk KNU. Series "Phys. Nucl., Part., Fields”. 2009, № 859, iss. 2(42), p. 89-94.

9. N.P. Dikiy, A.N. Dovbnya, E.P. Medvedeva, et al. Investigation of nanostructural characteristics of ma- 
terials for sorption cesium // Problems of Atomic Science and Technology. Series "Nuclear Physics Investigations”. 2011, № 3, p. 35-41.

10. N.P. Dikiy, A.N. Dovbnya, E.P. Medvedeva, et al. Radioactive enhancement of methanol conversion by zinc oxide nanoparticles // Problems of Atomic Science and Technology. Series "Nuclear Physics Investigations”. 2011, № 5, p. 48-57.

11. N.P. Dikiy, A.N. Dovbnya, E.P. Medvedeva, et al. Modification of nanomaterials by radiation // Problems of Atomic Science and Technology. Series "Nuclear Physics Investigations”. 2016, № 5, p. 83-87.

12. I.D. Fedorets, N.P. Khlapova, N.P. Dikiy, et al. Effects of gamma-activation and functionality characteristics of super dispersed $\mathrm{ZrO}_{2}$-catalystes in meth- anol conversion // Vestnyk KNU. Series "NPF". 2012, № 1025, iss. 4(56), p. 77-83.

13. N.I. Aizatsky, N.P. Dikiy, A.N. Dovbnya, V.A. Kushnyr, et al. Influence of irradiation with high-energy electrons on the properties of zirconium dioxide nanoceramics // Problems of Atomic Science and Technology. Series "Nuclear Physics Investigations”. 2013, № 6, p. 161-164.

14. H. Forster. UV/Vis Spectroscopy // Mol. Sieves. 2004 , v. 4, p. $337-426$

15. M. Sinev. Free radicals in catalytic oxidation of light alkanes: Kinetic and thermo-chemical aspects // $\mathrm{J}$. Catal. 2003, v. 216(1-2), p. 468-476.

16. K. Tanabe. Surface and catalytic properties of $\mathrm{ZrO}_{2}$ // Mat. Chem. Phys. 1985, v. 3, p. 747-764.

Article received 03.06.2021

\title{
РАДИАЦИОННАЯ СТИМУЛЯЦИЯ КАТАЛИТИЧЕСКОЙ АКТИВНОСТИ НАНОЧАСТИЦ ДИОКСИДА ЦИРКОНИЯ В ПРОЦЕССАХ КОНВЕРСИИ УГЛЕВОДОРОДОВ
}

\author{
Н.П. Дикий, Ю.В. Ляико, Е.П. Медведева, Д.В. Медведев
}

Проведено сравнение каталитической активности исходных и активированных тормозным $\gamma$-излучением на сильноточном электронном ускорителе наночастиц диоксида циркония на характер конверсии этанола. Используемые параметры $\gamma$-активации способствовали формированию более совершенной кристаллической структуры наночастиц $\mathrm{ZrO}_{2}$. Показано, что при использовании в качестве катализатора $\gamma$-активированных наночастиц $\mathrm{ZrO}_{2}$ выход углеводородных продуктов при конверсии этанола превышал в несколько раз выход таких же продуктов в случае использования исходных наночастиц $\mathrm{ZrO}_{2}$. Механизм подобной конверсии этанола может быть связан с синергизмом больших ионизационных потерь Оже-электронов и воздействием высокореакционных продуктов, участвующих в гетерогенном катализе.

\section{РАДІАЦЙНА СТИМУЛЯЦІЯ КАТАЛІТИЧНОЇ АКТИВНОСТІ НАНОЧАСТИНОК ДІОКСИДУ ЦИРКОНІЮ У ПРОЦЕСАХ КОНВЕРСІЇ ВУГЛЕВОДНІВ}

\section{М.П. Дикий, Ю.В. Ляико, О.П. Медведєва, Д.В. Медведєв}

Проведено порівняння каталітичної активності вихідних та активованих гальмівним $\gamma$-випромінюванням на потужному прискорювачі електронів наночастинок діоксиду цирконію на характер конверсії етанолу. Параметри $\gamma$-випромінювання, які використовували, сприяли формуванню більш досконалої кристалічної структури наночастинок $\mathrm{ZrO}_{2}$. Показано, що у випадку використання у якості каталізатора $\gamma$-активованих наночастинок $\mathrm{ZrO}_{2}$ вихід вуглеводних продуктів при конверсії етанолу підвищується у декілька разів відносно таких же продуктів у разі використання вихідних наночастинок $\mathrm{ZrO}_{2}$. Механізм подібної конверсії етанолу може бути пов'язаним з синергізмом великих іонізаційних втрат Оже-електронів та впливом високо реакційних продуктів, які приймають участь у гетерогенному каталізі. 